\title{
Subsurface management model: interdisciplinary approach in conditions of contemporary challenges, risks and uncertainties
}

\author{
$Y u . V$. Lebedev, K.V. Kokarev, A.V. Gorbunov, and L.N. Oleynikova \\ Ural State Mining University, 620144, Kuibyshev st., 30, Ekaterinburg, Russia
}

\begin{abstract}
Difficult environmental, economic, social and political conditions require an in-depth analysis of interdisciplinary relationships at industrial areas. The "Subsurface Management System" is a complex of developed subsoil resource fields characterized by geological, geomechanical and aerogasdynamic processes, and industries linked with each other through flows of energy, matter and information, integrated with civil society and environment. The flow of biogenic elements in subsurface management areas tend to increase the physical flows exporting the elements of biological product flow to the global ocean. The flows of energy in subsurface management areas in form of clean primary production of bioenvironment are changing fundamentally towards expansion of anthropogenic (man-made) factor channel by $8-12 \%$. The flows of environmental information in subsurface management areas contain details about compliance of the environmental conditions with biological regelation. The introduced original term "subsurface management system" accounts for distribution of flows of energy, matter and information between the system components, enabling objective analysis of effective performance of the system and its compliance with sustainable development strategy of industrial areas.
\end{abstract}

\section{Relevance}

Difficult environmental (environment pollution and transformation), economic (reduction of available mineral resources), social (wealth divide increase, growth of protest activity in civil society) and technological situation (low-grade deposits featuring complex structure, geodynamical risks, finely disseminated ore) require an in-depth analysis of connections between natural, economic, social and technology factors in the mining areas. A clear interpretation of the term "subsurface management system" is important in terms of interdisciplinary feasibility study of sustainable environmental development of the mining areas. 


\section{Goal of research}

To develop the subsurface management model based on interdisciplinary approach in conditions of contemporary grand challenges, risks and uncertainties; to outline relevant approaches to assessment of efficiency of subsurface management systems based on multicriteria valuation.

\section{Status of the problem}

The following understandings of subsurface management systems are common today.

R.L. Rayatskis and V.P. Stukaitis [1] proposed a production system model in the form of connections between environmental and technological relationships in 1981. Later on, D.M. Gwishiani [2] et al. (1986) specified requirements to environmental-economic models of production: incorporation of all cause-and-effect relationships, closed model cycle based on the following: direct links and feedback in the model, available criteria and goal setting in decision making, available assessment and environment support methodology, dynamic nature of the model.

M.E. Pevsner and V.P. Kostovetsky (1990) clearly specified that additional parameters characterizing "the effect of direct links and feedback between industry and environment" need incorporation with economic-mathematical models of economic management [3]. N.K. Shinkarenko (2013) proposed a structure of social-environmental-economic system of "contemporary mutually reinforcing functioning of mineral resources and industrial processing sectors within individual territories" [4]. In this model the author highlights "cross effect of economy, environment and social domain". Unfortunately, the presented model portrayed the state with its politics, legislation and economy as an outside party in relation to the environment. D.R. Kaplunov, M.V. Rylnikova, D.N. Radchenko (2013) proposed to change an approach to design of ore deposits development [5], based on fusion of analytical approaches developed in papers published by the school of thought of the Fellow of the Russian Academy of Science K.N. Trubetskoy with new concepts regarding integrated development and protection of subsurface resources. The study of the mining complexes behavior is based on minerals, geological, geomechanical, gas/aerodynamic, technological, economic and social processes, characterizing the mining complex in terms of its relationship with the environment. The following paper by D.R. Kaplunov, and D.N. Radchenko (2017) looks at the subsurface management system from sustainable development perspective, although within industrial interpretation of this concept [6].

L.A. Puchkov believes that global energy demand is a result of incorrect setting of economic management goals, and "financial-economic methods of prediction of global mineral and energy demand fail to take into consideration the key natural origin of these resources, which results in dramatic contradictions with natural development laws..." [7]. He is stating: "From perspective of the natural imperative of mineral and energy resources, they are material basis of development of civilization - the main goal of the natural evolution on Earth". And, finally, "the economy can be expected to become crisis-free, if further development of the global civilization is coordinated with the laws of nature".

V.P. Pakhomov and E.A. Atamanova suggested a 3D subsurface management structure, which reflects diversity of relationships originating between phenomena and processes in mining [8]. Strict ranking of the system objects (ecological space from outside, subsurface resources management object - sites of developed deposits inside the system) and consideration of spatiotemporal dynamics of subsurface management objects are the key parts of this subsurface management model. The subsurface management system is represented in the papers by V.L. Yakovlev and S.V. Kornilkov $[9,10,11]$ as technological platform, integrating processes in administrative units' territories; in this case, the subsurface 
management system is interpreted as "organization of enterprises ... consuming resources from outside". Not only is the system of subsurface management companies characterized by "consumption of external resources", but also by impacts of such consumption on the enterprise itself (changes of resource base conditions, market relations risks), on the environment (disturbance of biotic regulation in the regions), on community (the interests of individual users of subsurface resources must be harmonized with those of society), and also in conditions of contemporary challenges and risks.

Technological factor of the territories' development is studied in the work of A.V. Dushin and V.V. Balashenko [12]. The authors determined that the Urals sector of the Arctic Region can be developed, only provided that transportation and energy infrastructure is established. The natural (environmental) aspect of development of the territories is studied here from the perspective of "increased resources management effectiveness". The study elaborates an approach from "feasibility" assessment of environmental and resource potential to "socialeconomic" assessment.

Therefore, the trend to take into account the relations of technological processes with ecological, economic and social environment at industrial areas leads to taking the flows of energy (in natural and man-made channels), matter (resources and products) and information (biological, social, economic and technological) into account on the basis of interdisciplinary approach.

A comprehensive solution of effective functioning of "subsurface management systems" and healthy life support of the civil society within them is required.

\section{Results}

A formalized model of subsurface management system in conditions of contemporary challenges, risks and uncertainties is proposed.

The "subsurface management system" is a complex of developed subsurface fields (characterized by geological, geomechanical and aerogasdynamic processes), industries (geological exploration, development and processing of minerals, their high-level processing, management and disposal of wastes) integrated by flows of energy, matter and information with each other, and with civil society (socium) and environment (atmospheric air, water, soil and vegetation cover). Formalized diagram of the "subsurface management system" based on interdisciplinary approach is presented on Figure 1. 


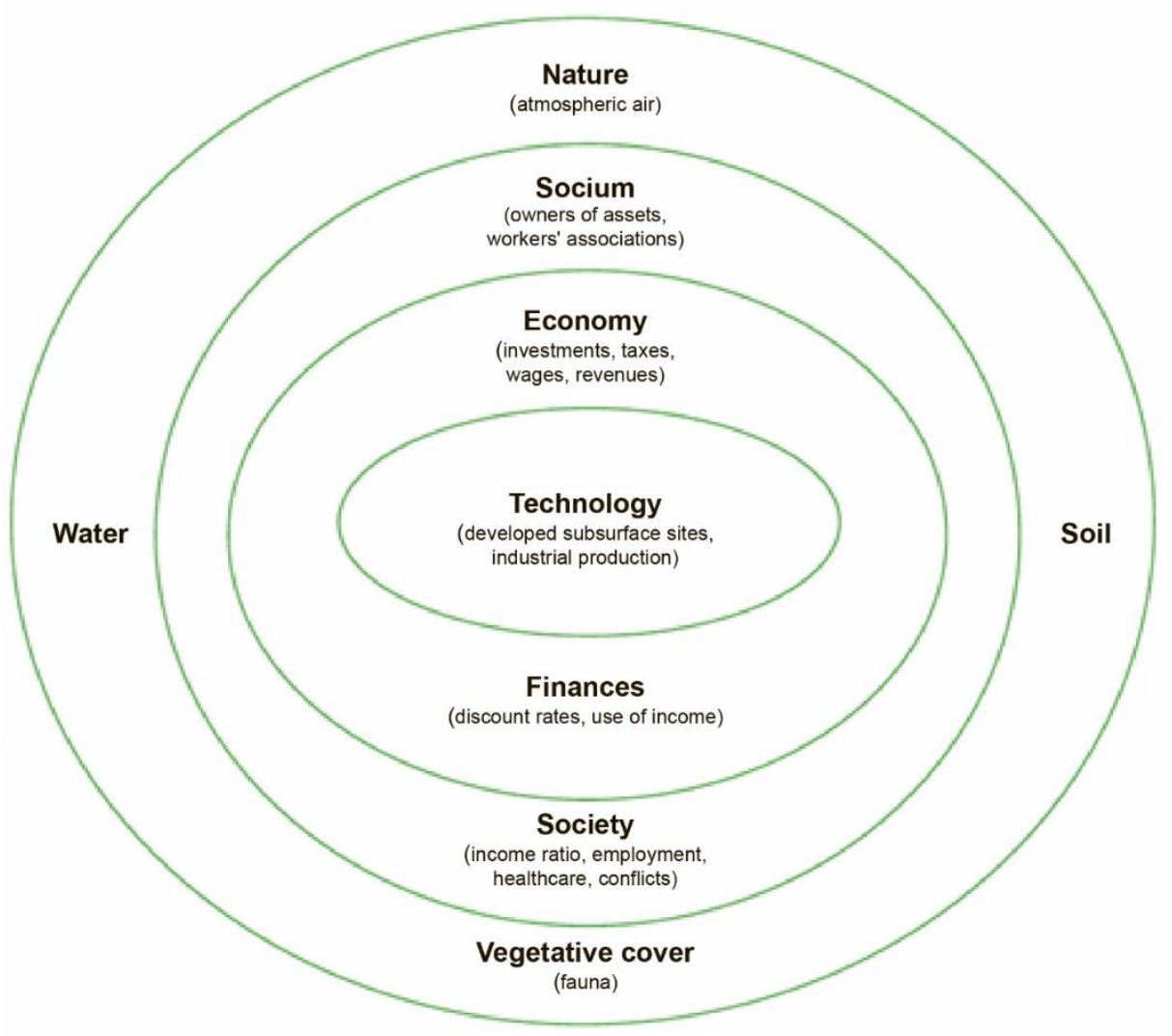

Fig. 1. Formalized diagram of the "subsurface management system" based on interdisciplinary approach

This system takes into account the background (development of vegetation and fauna, generation of minerals, evolution of vegetation), and current condition and future implications of subsurface management.

The general description of flows of energy, matter and information within subsurface management systems is provided in the Table 1 .

Table 1. Flows of energy, matter and information within subsurface management systems (based on interdisciplinary approach)

\begin{tabular}{|c|c|c|c|}
\hline \multirow{2}{*}{$\begin{array}{l}\text { Components } \\
\text { of } \\
\text { subsurface } \\
\text { management } \\
\text { system }\end{array}$} & \multicolumn{3}{|c|}{ Flows in components of subsurface management system } \\
\hline & Energy & Matter & Information \\
\hline $\begin{array}{l}\text { Environment } \\
\text { (nature) }\end{array}$ & $\begin{array}{l}\text { Biochemical links in } \\
\text { vegetation cover. } \\
\text { Preserved energy in } \\
\text { potential reserves of } \\
\text { hydrocarbon } \\
\text { subsurface fields. }\end{array}$ & $\begin{array}{l}\text { Atmospheric air } \\
\text { composition. } \\
\text { Biological resources } \\
\text { (vegetation). } \\
\text { Biogenic elements } \\
\text { flows. }\end{array}$ & $\begin{array}{l}\text { Genetic information of } \\
\text { organism species. } \\
\text { Transformation of } \\
\text { environment. } \\
\text { Compliance of environmental } \\
\text { conditions with biotical } \\
\text { regulation. }\end{array}$ \\
\hline
\end{tabular}




\begin{tabular}{|c|c|c|c|}
\hline Civil society & $\begin{array}{l}\text { Social energetics. } \\
\text { Power of thought, } \\
\text { mind. } \\
\text { Power of observing the } \\
\text { moral laws. } \\
\text { Power of social } \\
\text { conflicts. }\end{array}$ & $\begin{array}{l}\text { Foods (incl. those } \\
\text { produced at } \\
\text { subsurface } \\
\text { management sites). } \\
\text { Water resources } \\
\text { (degree of damage, } \\
\text { pollutions). } \\
\text { Atmospheric air } \\
\text { (ionized oxygen, } \\
\text { phytoncids). }\end{array}$ & $\begin{array}{l}\text { Employment of population in } \\
\text { economy in economy. } \\
\text { Public health. } \\
\text { Income-based stratification of } \\
\text { society along revenue in } \\
\text { mining companies }\end{array}$ \\
\hline Economy & $\begin{array}{l}\text { Power of interaction of } \\
\text { the authority (state), } \\
\text { industry (business) and } \\
\text { civil society } \\
\text { (workers' association) }\end{array}$ & $\begin{array}{l}\text { Financial assets and } \\
\text { their equivalents. } \\
\text { Investments in } \\
\text { subsurface } \\
\text { management. } \\
\text { Different taxes. } \\
\text { Use of revenues in } \\
\text { subsurface } \\
\text { management systems. }\end{array}$ & $\begin{array}{l}\text { Regional (national) wealth, } \\
\text { natural capital. } \\
\text { Environmental potential, } \\
\text { industrial potential. } \\
\text { GDP parameters. } \\
\text { Discount rates, discounting } \\
\text { index. } \\
\text { Centralized decisions. } \\
\text { Indicative planning. }\end{array}$ \\
\hline $\begin{array}{l}\text { Industry, } \\
\text { technologies }\end{array}$ & $\begin{array}{l}\text { Increased power } \\
\text { consumption at low- } \\
\text { grade ore deposits, } \\
\text { small size and } \\
\text { multiple-structured } \\
\text { deposits. } \\
\text { Energy of moved } \\
\text { masses at mining } \\
\text { plants. } \\
\text { Energy of renewables } \\
\text { (sun, wind, } \\
\text { geothermal) }\end{array}$ & $\begin{array}{l}\text { Developed minerals: } \\
\text { coal, oil, gas, ores of } \\
\text { ferrous and non- } \\
\text { ferrous metals etc. } \\
\text { Products of their } \\
\text { processing. } \\
\text { Flows of technogenic } \\
\text { pollution. }\end{array}$ & $\begin{array}{l}\text { Natural processes in deposits. } \\
\text { Industrial processes: } \\
\text { Exploration, production, } \\
\text { enrichment, processing of } \\
\text { minerals, disposal of wastes. } \\
\text { Goals of subsurface } \\
\text { management development. } \\
\text { Optional solutions of } \\
\text { subsurface management } \\
\text { problems. } \\
\text { Ways of effective utilization } \\
\text { of subsurface management } \\
\text { techniques, capacities, } \\
\text { specialists. }\end{array}$ \\
\hline
\end{tabular}

The flows of energy, matter and information in "subsurface management systems" are functioning in the environmental, social, economic and technological domains.

The proposed model of subsurface management systems is a self-contained model (environment and socium/state are inside the system circle), it incorporates all main effective cause-and-effect relationships (ecology is not an additional factor and community is not ignored), includes goal sets and assessment criteria enabling support of the environment in contemporary progress dynamics (challenges, risks, uncertainties).

\section{Energy flows in subsurface management systems}

The flows of energy can be understood as the most generalized fundamental characteristics of natural-manmade objects. From materialistic position perspectives, the energy [13] is a general quantity-related measure of different forms of motion of matter. Humanitarian approach offers more comprehensive definition of the energy [14].

In the environmental segment of the subsurface management system (Fig. 1) the energy flows are manifested in the form of energy of biochemical bonds in vegetation, generated during photosynthesis. In pre-industrial period humans consumed 1-2\% of clean initial energy of the environment; whereas $8-12 \%$ of nature's energy is consumed through anthropogenic channel today $[15,16]$. 
In the social domain of subsurface management system (Fig. 1) the flows of energy represent social energetics form [17], power of thought and mind [18], observing the moral laws, power of social conflicts.

The social energetics [19] expose human efforts focused on maintaining, storage, protection from dispersion and pillage of converted forms of solar power required to meet human demands. The power of thought and mind is manifested during improvement of domestic, artistic, and working conditions of life. Different artistic associations of people, associations of inventors, and efficiency experts in teams of the mining complexes that existed earlier, represented manifestation of this type of energy [20]. The energy of intellectual activity is expressed in patent research in the mining industry, in patent protection of the new developments and in their records in inventory of intangible assets.

The energy of social conflicts is expressed by response of the civil society to conditions and changes with environmental, social and economic domains of the subsurface management system [21].

The energy flows in economic domain of subsurface management systems are expressed in the energy of interaction of authority (the state), industry (business) and civil society (workers' associations).

The role of authority (government) in improvement and development of subsurface management in conditions of major challenges is about analysis of environmental, economic, social and technological aspects of the mining industry, rationalizing priorities of science and technology development of the region and most critical scopes of its innovative development, within which terms technologies are created and used, solutions providing most effective responses to contemporary challenges (risks, uncertainties) are implemented. The role of business in improvement and development of subsurface resources management in the Urals and Western Siberia is to tackle the issue of close-mindedness regarding practical application of results of research and development, to eliminate the "fear" of overcoming "associated" costs of research and implementation of disruptive technology of the subsurface resources management. The role of civil society in improvement and development of the subsurface management lies in empowering the environmental awareness of the public and long term motivation of subject of the subsurface management, in generation of friendly conditions of partnership between community and the government, in "bringing up" the national professional leaders.

In the industry and technology domain of subsurface management system (Fig. 1) the flows of energy include chemical, mechanical (incl. transportation), thermal, electromagnetic, and gravitational energy. This energy is the bread and butter for the mining complex development [22, 23]. Mining is one of the most power-consuming industries [24]. Its share ranges from 4 to $55 \%$ in different countries' power consumption structure [25]. Involvement with development of low-grade ores, small-size deposits and multiplestructured deposits, adverse mining/geological and natural and climatic conditions result in increased power consumption within subsurface management [24, 26]. Unconventional energy sources start being used [27]: rock pressure and elastic vibrations of the rock mass (for rock destruction) to generate electric power by means of special converters, and drop energy of backfill mixtures migrating from the top into mined-out spaces, gravity power of heavy mining and transportation equipment, energy of spent air flows of mines' ventilation system etc. According to statement in reference [25], the whole potential energy of solid, liquid and, gaseous matters moved over the mining plant can be effectively converted into renewable electric power.

There's some room for "green" energy in the future, primarily it applies to solar and wind power [28], the trend of duplication of power generated by new energy every 4-5 years is in progress [29]. 
The "green" energy will also enjoy progress in Russia, though not as rapidly, since the subsurface resources make provision for quite a long term and effective use of conventional energy sources [30].

According to the American "U.S. Energy information Administration" forecast, the global share of renewable energy sources ranges from 5\% [31] to $6.4 \%$ by 2040 . According to K.K. Ilkovsky and D. I. Timopheyev [32], "development of "green" energy is rather focused on some groundwork for the future than on operational targets of current energy preservation."

\section{Flows of matter in subsurface management systems}

The flows of matter in environmental domain of subsurface management systems (Figure 1) include changing constitution of the atmospheric air (increase of $\mathrm{CO} 2$ [33], presence of gaseous [34], airborne and dust pollutions), transformed biological resources (vegetation and fauna), changed flows of biogenic elements [35], aquatic resources with levels of their pollution [36].

The flows of matter in social domain of subsurface management systems include environmental components (air, water) forming favorable living conditions, food flows ensuring good living standard, and domestic waste flows.

The flows of matter in economic domain of subsurface management systems (Fig. 1) include assets and their tangible equivalents: income, investments, taxes, charges and others, and usage pattern of income in the subsurface management systems.

Fig. 2 displays net profit distribution in the Russian oil complex. $27 \%$ of profit was spent on dividends, and only $6 \%$ was spent on investments [37].

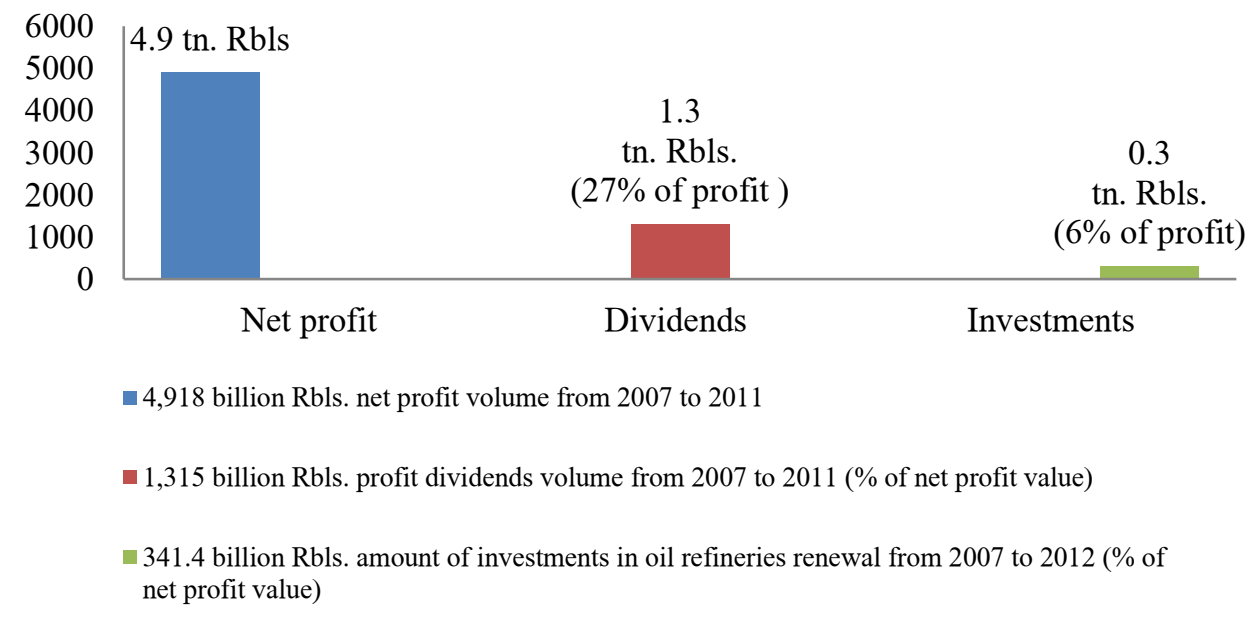

Fig. 2. Financial indicators in the Russian oil complex [37]

Fig. 3 displays R\&D costs among the largest global oil producing companies. 


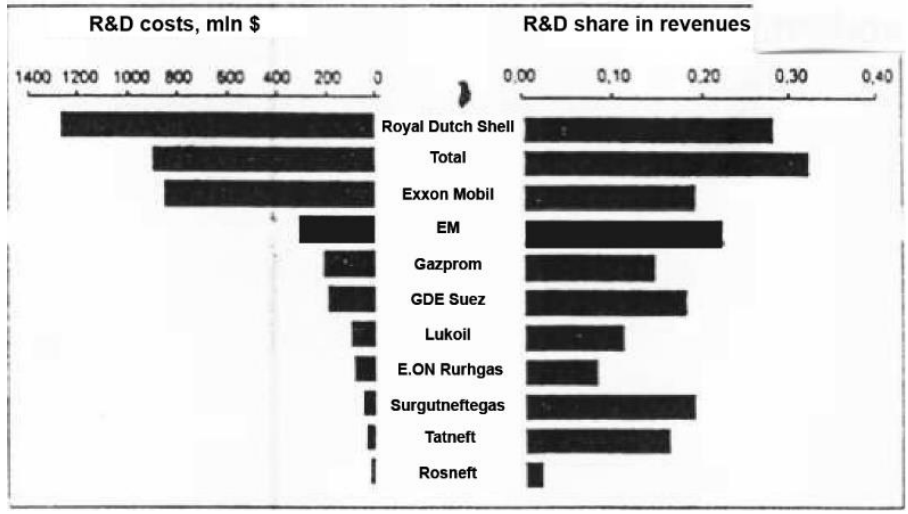

Fig. 3. R\&D costs over the largest global oil producing companies

It is clear that costs of research and development are minimized in the largest Russian oil producing companies (Lukoil, Surgutneftegas, Tatneft, Rosneft) and their share in profit amounts to $2 \%$ (Rosneft) - $8 \%$ (Lukoil); he same value is more than $25 \%$ and already reaching $35 \%$ among foreign oil producing companies.

According to officially published information, the sales revenue at the Kachkanarsky ore mining and dressing plant amounted to 24,308 million Rubles with the net profit 11,013 Rubles in 2010 , the profit margin was $45,3 \%$. The profit came up to about 15 billion (the Urals Division), and profit margin dropped to $15 \%$ in 2017 [38]. This is a common trend within mining and metallurgy sector in the country.

The flows of matter in industrial domain of subsurface management systems are shaped by changing geopolitical environment, achievements of scientific and technological progress, reduced demands in some minerals and increased demand in others. According to Strategy of development of mineral and resource base of the Russian Federation until 2030 [39], the long-term plans make provision for transition from the current model of high tonnage export and mineral-resource based self-support to the model designed as economically justified balance between sufficient domestic consumption, significant export and required import of mineral raw materials. Table 2 lists balance reserves of the iron ore in deposits of the Kachkanarsky ore mining and dressing plant [40]. Table 3 provides general properties of the ore in pits of Gusevgorsky deposit [41].

Table 2. Reserves of titanium magnetite ores of Kachkanarsky ore mining and dressing plant [40]

\begin{tabular}{|l|c|c|}
\hline \multirow{2}{*}{\multicolumn{1}{c|}{ Ore deposits }} & \multicolumn{2}{|c|}{ Balance reserves of iron ore as of 01.01.2013, mil. tons } \\
\cline { 2 - 3 } & $\mathrm{A}+\mathrm{B}+\mathrm{C}_{1}$ & $\mathrm{C}_{2}$ \\
\hline Gusevgorsky & $2,543.3$ & $2,410.3$ \\
\hline Kachkanarsky proper & $3,602.6$ & $3,269.9$ \\
\hline
\end{tabular}

Table 3. Types of ores at Gusevgorsky deposit based on preparability and ore types [41]

\begin{tabular}{|l|c|c|c|c|c|c|}
\hline \multirow{2}{*}{ Pit } & \multicolumn{2}{|c|}{$\begin{array}{c}\text { Share of ores based on preparability (impregnation, } \\
\text { concentration of iron in magnetic fraction), }\end{array}$} & \multicolumn{2}{c|}{ Share of ore types, \% } \\
\cline { 2 - 7 } & $\begin{array}{c}\text { Free- } \\
\text { milling } \\
\text { ores }\end{array}$ & $\begin{array}{c}\text { Standard } \\
\text { enrichment } \\
\text { ores }\end{array}$ & $\begin{array}{c}\text { Medium } \\
\text { enrichment } \\
\text { ores }\end{array}$ & $\begin{array}{c}\text { Difficult } \\
\text { ores }\end{array}$ & $\begin{array}{c}\text { Low } \\
\text { titanium }\end{array}$ & $\begin{array}{c}\text { Standard } \\
\text { titanium }\end{array}$ \\
\hline Northern & 1.1 & 26.5 & 30.1 & 42.3 & 61.0 & 39.0 \\
\hline M & 1.6 & 10.5 & 23.0 & 64.9 & 28.0 & 72.0 \\
\hline
\end{tabular}


As an example of the flows of matter in mining domain of subsurface management systems in form of various products, Table 4 lists the product of the mining diversification on the North Caucasus [42].

\section{Information flows in subsurface management systems}

The information about production is becoming the most critical part of its background [43]. It is suggested to consider the post-industrial stage of development of civilization as that of information. From abstract points of view, all properties of energy and matter flows in the Table 1 above can be referred to as parts of "common" information about production systems.

\section{Environmental information flows in subsurface management systems}

In the ecological/environmental domain of domain of subsurface management systems (Fig. 1) the information flows integrate biological species of communities preserving genetic information regarding the best bioenvironment for living, and ways of compensations for damages of its normal condition. In practice, the flows of environmental information in subsurface management systems contain details about transformation of environmental media at genetic level (impact of technogenic pollution on genetic codes of life forms), on species level (change of biodiversity at industrial areas - reduction of indigenous species and distribution of species unrepresentative of given locations), and on ecosystem level (replacement of indigenous vegetation types by derived types).

Table 4. Products of mining diversification

\begin{tabular}{|l|l|l|}
\hline \multicolumn{1}{|c|}{ Lines of process } & \multicolumn{1}{|c|}{ Innovative technology } & \multicolumn{1}{|c|}{ New product } \\
\hline $\begin{array}{l}\text { Metal mining } \\
\text { Sadonsky lead and zinc plant }\end{array}$ & $\begin{array}{l}\text { Underground leaching of } \\
\text { substandard reserves }\end{array}$ & $\begin{array}{l}\text { Gel concentrate of metals and } \\
\text { salts, construction raw } \\
\text { materials, demineralized } \\
\text { water, chlorine, hydrogen, } \\
\text { oxygen, acids and alkali }\end{array}$ \\
\hline $\begin{array}{l}\text { Metallic ores processing } \\
\text { OJSC "Electrozinc" }\end{array}$ & $\begin{array}{l}\text { Hydrometallurgical processes } \\
\text { instead of pyrometallurgical }\end{array}$ & $\begin{array}{l}\text { Metals and salts, construction } \\
\text { raw materials, demineralized } \\
\text { water, chlorine, hydrogen, } \\
\text { oxygen, acids and alkali }\end{array}$ \\
\hline $\begin{array}{l}\text { Processing of metallurgy } \\
\text { tailings } \\
\text { OJSC "Electrozinc" }\end{array}$ & $\begin{array}{l}\text { Combined mechanical and } \\
\text { chemical activation of leaching }\end{array}$ & $\begin{array}{l}\text { Metals and salts, construction } \\
\text { raw materials, demineralized } \\
\text { water, chlorine, hydrogen, } \\
\text { oxygen, acids and alkali }\end{array}$ \\
\hline $\begin{array}{l}\text { Processing of milltailings } \\
\text { Sadonsky lead and zinc plant }\end{array}$ & $\begin{array}{l}\text { Combined mechanical and } \\
\text { chemical activation }\end{array}$ & $\begin{array}{l}\text { Gel concentrates, flux } \\
\text { material, sand, sludge } \\
\text { fraction, cementitious et al }\end{array}$ \\
\hline $\begin{array}{l}\text { Mine drains treatment } \\
\text { Sadonsky lead and zinc plant }\end{array}$ & $\begin{array}{l}\text { Electrochemical purification } \\
\text { with electrodialysis } \\
\text { desalinization }\end{array}$ & $\begin{array}{l}\text { Gel concentrate of metals and } \\
\text { salts, construction raw } \\
\text { materials, demineralized } \\
\text { water, chlorine, hydrogen, } \\
\text { oxygen, acids and alkali }\end{array}$ \\
\hline $\begin{array}{l}\text { Production of dolomite } \\
\text { minerals } \\
\text { OJSC "Kavdolomit" }\end{array}$ & $\begin{array}{l}\text { Mechanical activation in } \\
\text { desintegrators }\end{array}$ & $\begin{array}{l}\text { Hyperfine components for } \\
\text { fabrication of fillers }\end{array}$ \\
\hline
\end{tabular}


Production of sand-andgravel stuff materials Pits
Panning of alluvial deposits with process activity increase
Gold and virgin metals, construction raw materials, sludge fraction

\section{Public health}

In spite of certain increase of average life expectancy, increase of the following diseases is observed: nervous disorders, blood circulation diseases, respiratory diseases, digestive system diseases. Deterioration of environment in industrial areas, increasing gap between the rich and the poor results in high incidence of psychic disorders and substance abuse in industrial regions.

Tables 5 and 6 below summarize this data for specific industrial regions in the Middle Urals. Consistent increase of psychic disorders among children and teenagers in industrial regions is raising concerns in social dimension (Table 7).

Table 5. Rates of psychic disorders of the population of industrial districts in the Sverdlovsk Region

\begin{tabular}{|l|c|c|c|c|c|c|}
\hline \multirow{2}{*}{ District (area) } & \multicolumn{3}{c|}{ Sick rate, by year } & \multicolumn{3}{c|}{ Primary disease incidence, } \\
\cline { 2 - 7 } & 2008 & 2009 & 2010 & 2008 & 2009 & 2010 \\
\hline $\begin{array}{l}\text { Yekaterinburg (1,386.5 } \\
\text { thousand people) - engineering } \\
\text { industry }\end{array}$ & 1974 & 2670 & 2129 & 287 & 360 & 299 \\
\hline $\begin{array}{l}\text { Nizhny Tagil (361.4 thousand } \\
\text { people) - iron and steel works }\end{array}$ & 1202 & 2593 & 2353 & 87 & 400 & 691 \\
\hline $\begin{array}{l}\text { Kamensk-Uralskiy (176.5 } \\
\text { thousand people) - nonferrous } \\
\text { metal production }\end{array}$ & 1541 & 1995 & 2884 & 137 & 229 & 329 \\
\hline $\begin{array}{l}\text { Pervouralsk (149 thousand } \\
\text { people) }\end{array}$ & 1580 & 3659 & 4478 & 65 & 773 & 773 \\
\hline $\begin{array}{l}\text { Serov (101.2 thousand people) } \\
\text { - metallurgical production }\end{array}$ & 3312 & 2435 & - & 67 & 679 & - \\
\hline $\begin{array}{l}\text { Asbest (98.7 thousand people) - } \\
\text { Production and processing of } \\
\text { asbestos }\end{array}$ & 1884 & 3254 & - & 335 & 347 & - \\
\hline $\begin{array}{l}\text { Kachkanar (38.4 thousand } \\
\text { people) - } \\
\text { Production of iron ore }\end{array}$ & 1477 & 1784 & 1898 & 72 & 477 & 393 \\
\hline $\begin{array}{l}\text { Kushwa (27.6 thousand people) } \\
\text { production and processing of } \\
\text { iron ore }\end{array}$ & 2801 & 1777 & 1873 & 331 & 411 & 524 \\
\hline $\begin{array}{l}\text { Rezh (36.8 thousand people)- } \\
\text { production and processing of } \\
\text { nonferrous metal ore }\end{array}$ & 3986 & 3271 & 2601 & 469 & 416 & 461, \\
\hline
\end{tabular}

Note: The data was provided by Regional Governmental Institution of Healthcare "The Sverdlovsk Region Psychiatric Hospital” (Form 10, 2010).

Table 6. Rate of substance abuse in the population of industrial districts in the Sverdlovsk Region (as of 2009)

\begin{tabular}{|c|c|c|c|c|}
\hline \multirow{2}{*}{ District (area) } & \multicolumn{2}{|c|}{$\begin{array}{c}\text { Total sick rate per 100,000 } \\
\text { people }\end{array}$} & \multicolumn{2}{c|}{$\begin{array}{c}\text { Primary disease incidence } \\
\text { per100,000 people }\end{array}$} \\
\cline { 2 - 5 } & Alcoholism & Drug abuse & Alcoholism & Drug abuse \\
\hline $\begin{array}{l}\text { Yekaterinburg (1,386.5 } \\
\text { thousand people) }\end{array}$ & 530 & 366 & 102 & 75 \\
\hline
\end{tabular}




\begin{tabular}{|l|c|c|c|c|}
\hline $\begin{array}{l}\text { Nizhny Tagil (361.4 thousand } \\
\text { people) }\end{array}$ & 553 & 399 & 75 & 33 \\
\hline $\begin{array}{l}\text { Kamensk-Uralskiy (176.5 } \\
\text { thousand people) }\end{array}$ & 2723 & 511 & 79 & 18 \\
\hline $\begin{array}{l}\text { Pervouralsk (149 thousand } \\
\text { people) }\end{array}$ & 812 & 386 & 63 & 14 \\
\hline Serov (101.2 thousand people) & 975 & 214 & 82 & 51 \\
\hline Asbest (98.7 thousand people) & 1.385 & 459 & 66 & 36 \\
\hline $\begin{array}{l}\text { Alapayevsk municipal district } \\
\text { (without the town of } \\
\text { Alapayevsk) }\end{array}$ & 581 & 8.3 & 5.5 & 0 \\
\hline Bisertsky urban district & 361 & 47.5 & 9.5 & 0 \\
\hline
\end{tabular}

Note: The data is provided by the drug abuse monitoring office of the Sverdlovsk Region (2010).

Table 7. Numbers of registered patients with psychic disorders in the Middle Urals (according to data provided by the Sverdlovsk Region Psychiatric Hospital)

\begin{tabular}{|c|c|c|c|c|c|c|}
\hline \multirow{2}{*}{ Year } & \multicolumn{3}{|c|}{ Total number } & \multicolumn{3}{c|}{ Percentage of population } \\
\cline { 2 - 7 } & total & children & teenagers & total & children & teenagers \\
\hline 2013 & 103,551 & 16,836 & 4,970 & 2.5 & 2.6 & 4.2 \\
\hline 2014 & 104,858 & 17,525 & 5,053 & 2.5 & 2.6 & 4.6 \\
\hline 2015 & 106,923 & 17,923 & 5,253 & 2.6 & 2.6 & 4.8 \\
\hline 2016 & 107,272 & 18,629 & 5,358 & 2.6 & 2.6 & 5.0 \\
\hline 2017 & 109,977 & 19,699 & 5,735 & 2.6 & 2.6 & 5.3 \\
\hline
\end{tabular}

\section{Reference}

1. R.L. Rayatskis, V.P. Stukaitis, Environment and planning challenges, 272 (Moscow: Science, 1981)

2. D.M. Gwishiani, System studies. Methodology issues, 360 (Moscow: Science, 1986)

3. M.E. Pevsner, V.P. Kostovetsky, Ecology of mining, 230 (Moscow: Nedra Press, 1990)

4. N.K. Shinkarenko, Forming social-environmental-economic systems of goldmining in terms of restructurisation, 156 (St. Petersburg: Cult-inform Press, 2013)

5. D.R. Kaplunov, M.V. Rylnikova, D.N. Radchenko, The Mining Journal, 2, 101-104 (2013)

6. D.R. Kaplunov, D.N. Radchenko, 50 years of the Russian school of sciences of the integrated exploitation of interior part of the Earth, 345-350 (2017)

7. L.A. Puchkov, The Mining Journal, 4, 41-45 (2015)

8. V.P. Pakhomov, E.A. Atamanova, Theory and methodology bases of 3D subsurface management, 206 (Yekaterinburg: IE Ural Department of Russian Academy of Sciences, 2011)

9. V.L. Yakovlev, S.V. Kornilkov, The Rusisan oryctognosy issues, 471-487 (Moscow, 2012)

10. V.L. Yakovlev, S.V. Kornilkov, Herald of the Ural Department of Russian Academy of Sciences, 2013/4 (46), 11-18 (2013)

11. V.L. Yakovlev, S.V. Kornilkov, The Mining Journal, 1, 4-9 (2015)

12. A.V. Dushin, V.V. Balashenko, The Mining Journal, 7, 38-43 (2013)

13. The Soviet encyclopedic dictionary, chief editor A.M. Prokhorov, $3^{\text {rd }}$ print, 1545 (Moscow: Soviet encyclopedia, 1984)

14. S.A. Podolinsky, Human labor and its relationship with energy distribution, 160 (Moscow: Beliye Alvy, 2005) 
15. V.G. Gorshkov, Botanical Journal, 11, 1579-1590 (1980)

16. P.M. Vitousek, P.R. Erlich, A.E. Erlich, P.A. Matso, Bioscience, 36, 368-373 (1986)

17. V.S. Chesnokov, S.A. Podolinsky, The age of globalization, 2, 181-187 (2010)

18. D.J. Markovitch, Social ecology, 173 (Moscow: Prosveshcheniye Press, 1991)

19. A.C. Bhaktivedanta, Swami Prabhupada. Life Comes from Life, 207 (Moscow: Bhaktivedanta Book Trust, 1991)

20. T.S. Rozhkova, L.N. Alyanykh, The Mining Journal, 5, 113-120 (2017)

21. I.P. Dobrovolsky, Pravda, 19 (2016)

22. M.V. Rylkikova, K.I. Strukov, V.V. Olizarenko, I.C. Turkin, The Mining Journal, 11, $71-76(2017)$

23. D.G. Zakirov, M.A. Muhamedshin, R.A. Fairalhmanov, A.V. Kykolayev, The Mining Journal, 6, 49 - 52 (2018)

24. L.A. Puchkov, The Mining Journal, 4, 41 - 45 (2015)

25. D.R. Kaplunov, M.V. Rylkikova, The Mining Journal, 9, 72 - 75 (2015)

26. L.A. Puchkov, The Mining Journal, 10, 4-10 (2017)

27. I. J. Bunin, M.V. Ryazantseva, A. L. Samusev, I. A. Khabarova, The Mining Journal, 11, 77 - 83 (2017)

28. R. Fücks, Intelligent Wachsen. Die grilne Revolution, 362 (Berlin: Hanser, 2014)

29. V.S. Arutyunov, Oil XXI: myths and realities of alternative energy sources, 210 (LLC "TD Algoritm", 2016)

30. Yu.I. Mamontov, S.A. Yeremin, Soviet Russia, 146 (2019)

31. U.S. Energy Information Administration. Annual Energy Outlook 2014 with projections to 2040 URL: https://www.eia.gov/outlooks/aeo/pdf/0383(2014).pdf

32. K.K. Ilkovsky, D.I. Timofeyev, The Mining Journal, 12, 73-75 (2011)

33. D.G. Zamolodchikov, Use and protection of Russia's natural resources, 1, $36-42$ (2013)

34. M. Treshow, Air pollution and life of plants, 535 (Moscow: Hydrometizdat, 1988)

35. V.I. Danilov-Danilyan, Environmental Challenge and Sustainable Development, 414 (Moscow: Progress-Traditsia, 2000)

36. N.Yu. Antoninova, G.M. Chaykina, L.S. Rybnikova, L.A. Shubina, A.L. Feldman, The Mining Journal, 1 (2012)

37. V.I. Kashin, Use and protection of Russia's natural resources, 3, 10-14 (2013)

38. A. Kushnarev, Regarding conflict with trade union and production development

39. Strategy of development of mineral and resource base of the Russian Federation until 2030 (Moscow, 2017)

40. A.V. Lyapunov, S.M. Nekrasov, B.G. Russkikh, The Mining Journal, 9, 5 (2013)

41. S.V. Kornilkov, A.N. Dmitriyev, A.E. Pelevin, A.M Yakovlev, The Mining Journal, 5, 88 (2016)

42. V.I. Golik, V.I. Komashchenko, The Mining Journal, 3, 43-47 (2017)

43. I.G. Polyanskaya, V.V. Yurak, Economy of Region, 14(3), 851-869 (2018) doi: 10.17059/2018-3-12 